\title{
Fall-applied Foliar Zinc for Pecans
}

\author{
J.L. Walworth, ${ }^{1}$ A.P. Pond, and G.J. Sower \\ Department of Soil, Water, and Environmental Science, University of Arizona, \\ 429 Shantz Building, \#38, Tucson, AZ 85721
}

\section{M.W. Kilby \\ Department of Plant Science, University of Arizona, 303 Forbes Building, Tucson, AZ 85721}

\section{Additional index words. Carya illinoinensis, 'Western Schley', Zinc Sulfate, Arizona}

Adequate $\mathrm{Zn}$ nutrition is critical for commercial pecan production. Providing sufficient $\mathrm{Zn}$ through soil application is particularly problematic in high $\mathrm{pH}$ desert soils, due to the low solubility of $\mathrm{Zn}$ in alkaline conditions, and also the complexation of soil $\mathrm{Zn}$ by carbonate minerals (Lindsay, 1979). Foliar Zn applications are more effective than soil applications and can provide adequate $\mathrm{Zn}$ for maximum growth and production (Malstrom et al., 1984). The most commonly used materials for this purpose are $\mathrm{ZnSO}_{4}, \mathrm{Zn}\left(\mathrm{NO}_{3}\right)_{2}$, and $\mathrm{NZn}$.

A typical $\mathrm{Zn}$ fertilization program in Arizona consists of spraying $\mathrm{ZnSO}_{4}$ directly on the pecan foliage beginning at budbreak, and continuing until vegetative growth has subsided (Kilby, 1985). In total, three to five applications of 2.2 to $3.4 \mathrm{~kg} \cdot \mathrm{ha}^{-1} \mathrm{Zn}$ are required at about 2 -week intervals. Total season application is usually about $10 \mathrm{~kg} \cdot \mathrm{ha}^{-1} \mathrm{Zn}$. Foliar $\mathrm{Zn}$ fertilization programs are effective for avoiding $\mathrm{Zn}$ deficiency problems in southwestern pecans, however, they are expensive and time-consuming.

Received for publication 3 Aug. 2005. Accepted for publication 7 Sept. 2005.

${ }^{1}$ Corresponding author; e-mail walworth@ag. arizona.edu.

Table 1. Zinc concentrations $\left(\mu \mathrm{g} \cdot \mathrm{g}^{-1}\right)$ in pecan bud and twig tissue from trees treated with different rates and timings of foliar $\mathrm{Zn}$ application.

\begin{tabular}{|c|c|c|c|c|c|}
\hline \multirow{2}{*}{$\begin{array}{l}\text { Application } \\
\text { time }\end{array}$} & \multirow{2}{*}{$\begin{array}{c}\text { Zn rate } \\
\left(\mathrm{kg} \cdot \mathrm{ha}^{-1}\right)\end{array}$} & \multicolumn{2}{|c|}{2003} & \multicolumn{2}{|c|}{2004} \\
\hline & & $\overline{B u d ~ Z n}$ & Twig Zn & $\overline{B u d ~ Z n}$ & Twig Zn \\
\hline None & 0 & $64 \mathrm{c}^{z}$ & $22 \mathrm{c}$ & $92 \mathrm{c}$ & $30 \mathrm{~d}$ \\
\hline Fall & 14 & $128 \mathrm{~b}$ & $37 \mathrm{~b}$ & $173 \mathrm{~b}$ & $75 \mathrm{~b}$ \\
\hline Fall & 28 & $150 \mathrm{a}$ & $53 \mathrm{a}$ & $275 a$ & $117 \mathrm{a}$ \\
\hline Spring & 14 & $63 \mathrm{c}$ & $21 \mathrm{c}$ & $150 \mathrm{bc}$ & $52 \mathrm{c}$ \\
\hline Spring & 28 & $64 \mathrm{c}$ & $21 \mathrm{c}$ & $205 \mathrm{~b}$ & $67 \mathrm{bc}$ \\
\hline
\end{tabular}

${ }^{2}$ Means in each column followed by the same letters are not significantly different at the $5 \%$ level. $\left.\mathrm{kg} \cdot \mathrm{ha}^{-1} \mathrm{Zn}\left(\mathrm{SO}_{4}\right)_{2}\right)$ or $10 \mathrm{~kg} \cdot \mathrm{ha}^{-1}\left(28 \mathrm{~kg} \cdot \mathrm{ha}^{-1}\right.$ $\left.\mathrm{Zn}\left(\mathrm{SO}_{4}\right)_{2}\right)$ of $\mathrm{Zn}$. The following springs, the same rates of $\mathrm{ZnSO}_{4}$ were applied in a five application split. Spring sprays began on 15 Apr. 2003 and 8 Apr. 2004 and were repeated every $14 \mathrm{~d}$. All Zn sprays were applied in 468 $\mathrm{L} \cdot \mathrm{ha}^{-1} \mathrm{H}_{2} \mathrm{O}$, and contained $1.75 \mathrm{~L} \cdot \mathrm{ha}^{-1} \mathrm{UAN}$ as an adjuvant.

In February 2003 and 2004, samples of the previous season's growth were collected by removing the end $15 \mathrm{~cm}$ from four branches per tree. The branches were then washed in a mild detergent, rinsed three times in deionized water followed by a rinsing in ultra pure water, and dried. The buds were then removed from the wood and each was ground separately. Leaf samples, consisting of 30 middle leaflets from middle leaves on lower fruiting branches, were collected every 2 weeks beginning in early May 2003 and 2004. Samples were immediately refrigerated, washed in the same manner as the branch samples, dried and ground. All tissue samples were dry-ashed, dissolved in $2 \mathrm{M}$ $\mathrm{HCl}$, and analyzed for $\mathrm{Zn}$ content on a Spectro Modula M120 ICP. Leaf area was measured on the samples taken at the end of July of both years using the digital imaging analysis method of O'Neal et al. (2002).

Analyses of bud and twig samples indicate that fall applications did elevate $\mathrm{Zn}$ in those tissues (Table 1). However leaf samples collected during the growing season did not follow this pattern (Table 2). In all cases, the trees receiving Spring $\mathrm{Zn}$ applications contained significantly more $\mathrm{Zn}$ than those receiving $\mathrm{Zn}$ the previous fall. Zinc concentrations in trees receiving fall applied $\mathrm{Zn}$ were similar to the control. Even though fall $\mathrm{Zn}$ applications did increase $\mathrm{Zn}$ in bud and twig tissues, there did not appear to be an effect on leaf $\mathrm{Zn}$ concentrations the next growing season. Surprisingly, $\mathrm{Zn}$ concentrations in all leaf samples increased rapidly after the 25 June 2003 sampling date. This was unexpected, and has not happened in other pecan trees we have monitored through the growing season. The reason for this is unknown.

Leaf areas, measured in late July, reflect the $\mathrm{Zn}$ status of the leaves collected at that time (Table 3). Leaf area was related to leaf $\mathrm{Zn}$ concentration by the following equation: area $\left(\mathrm{cm}^{2}\right)=0.0321 \times \mathrm{Zn}\left(\mu \mathrm{g} \cdot \mathrm{g}^{-1}\right)+19.712\left(r^{2}=\right.$ 0.662 ). Trees receiving the Spring 10 treatment had larger leaves than the control and fall treat-

Table 2. Zinc concentrations $\left(\mu \mathrm{g} \cdot \mathrm{g}^{-1}\right)$ in pecan leaf tissue from trees treated with different rates and timings of foliar $\mathrm{Zn}$ application.

\begin{tabular}{|c|c|c|c|c|c|c|c|c|}
\hline $\begin{array}{l}\text { Application } \\
\text { time } \\
2003\end{array}$ & $\begin{array}{l}\text { Zn rate } \\
\mathrm{kg} \cdot \mathrm{ha}^{-1}\end{array}$ & \multicolumn{7}{|c|}{ Date } \\
\hline None & 0 & $31 \mathrm{c}^{\mathrm{z}}$ & $25 \mathrm{c}$ & $22 \mathrm{c}$ & $21 \mathrm{c}$ & $94 \mathrm{c}$ & $84 \mathrm{c}$ & $66 \mathrm{c}$ \\
\hline Fall & 28 & $32 \mathrm{c}$ & $26 \mathrm{c}$ & $23 \mathrm{c}$ & $24 \mathrm{c}$ & $87 \mathrm{c}$ & $94 \mathrm{c}$ & $71 \mathrm{c}$ \\
\hline Spring & 14 & $62 \mathrm{~b}$ & $63 \mathrm{~b}$ & $76 \mathrm{~b}$ & $83 \mathrm{~b}$ & $149 \mathrm{~b}$ & $185 \mathrm{~b}$ & $173 \mathrm{c}$ \\
\hline Spring & 28 & $105 \mathrm{a}$ & $91 \mathrm{a}$ & $107 \mathrm{a}$ & $145 \mathrm{a}$ & $286 \mathrm{a}$ & $328 \mathrm{a}$ & $297 \mathrm{a}$ \\
\hline Fall & 5 & $22 \mathrm{~b}$ & $31 \mathrm{cb}$ & $19 \mathrm{~b}$ & $27 \mathrm{c}$ & $50 \mathrm{c}$ & $53 \mathrm{c}$ & $40 \mathrm{c}$ \\
\hline Fall & 10 & $21 \mathrm{~b}$ & $10 \mathrm{~d}$ & $10 \mathrm{~b}$ & $31 \mathrm{c}$ & $37 \mathrm{c}$ & $49 \mathrm{c}$ & $34 \mathrm{C}$ \\
\hline Spring & 5 & $52 \mathrm{a}$ & $50 \mathrm{ab}$ & $80 a$ & $88 \mathrm{~b}$ & $104 \mathrm{~b}$ & $128 \mathrm{~b}$ & $112 \mathrm{~b}$ \\
\hline Spring & 10 & $71 \mathrm{a}$ & $68 \mathrm{a}$ & $85 \mathrm{a}$ & $133 \mathrm{a}$ & $137 \mathrm{a}$ & $165 \mathrm{a}$ & $177 \mathrm{a}$ \\
\hline
\end{tabular}

${ }^{2}$ Means in each column for a given year followed by the same letters are not significantly different at the $5 \%$ level. 
Table 3. Area of leaves collected in July from pecan trees treated with different rates and timings of foliar $\mathrm{Zn}$ application.

\begin{tabular}{|c|c|c|c|}
\hline \multirow{2}{*}{$\begin{array}{l}\text { Application } \\
\text { time }\end{array}$} & \multirow{2}{*}{$\begin{array}{c}\text { Zn rate } \\
\left(\mathrm{kg} \cdot \mathrm{ha}^{-1}\right)\end{array}$} & \multicolumn{2}{|c|}{ Leaf area $\left(\mathrm{cm}^{2} /\right.$ leaf $)$} \\
\hline & & 2003 & 2004 \\
\hline None & 0 & $24.7{b c^{z}}^{2}$ & $20.1 \mathrm{a}$ \\
\hline Fall & 14 & $22.8 \mathrm{c}$ & $20.5 \mathrm{a}$ \\
\hline Fall & 28 & $24.4 \mathrm{bc}$ & $19.1 \mathrm{a}$ \\
\hline Spring & 14 & $27.8 \mathrm{ab}$ & $21.8 \mathrm{a}$ \\
\hline Spring & 28 & $28.1 \mathrm{a}$ & $23.5 \mathrm{a}$ \\
\hline
\end{tabular}

ments in 2003 but were not different from the spring $5 \mathrm{~kg} \cdot \mathrm{ha}^{-1}$ treatment. In 2004, there were no significant differences in leaf area.

The fall applied $\mathrm{Zn}$ applications tested in this study were ineffective. Although $\mathrm{Zn}$ applied at the end of the season did affect $\mathrm{Zn}$ concentrations in dormant season tissues, it had no effect on subsequent leaf Zn concentra- a prudent and reasonable application rate. Fall applications of $\mathrm{Zn}$ or rates below $28 \mathrm{~kg} \cdot \mathrm{ha}^{-1}$ are not recommended based on this research.

\section{Literature Cited}

Kilby, M.W. 1985.Zinc nutrition of pecan trees in Arizona, p. 9-19. Proceedings of the Western Pecan Conference, March 1985, Las Cruces, N.M.

Lindsay, W.L. 1979. Chemical equilibria in soils. The Blackburn Press, Caldwell, N.J.

Malstrom, H.L., L.B. Fenn, and T.R. Riley. 1984 Methods of zinc fertilization. Pecan South 11(3):16-19.

tions. Spring Zn applications increased both leaf tissue $\mathrm{Zn}$ concentrations and leaf area. The currently used commercial application level (about $28 \mathrm{~kg} \cdot \mathrm{ha}^{-1} \mathrm{ZnSO}_{4}$ ) provided only marginal improvement over a lower rate of $\mathrm{Zn}$. However, the higher rate of $\mathrm{Zn}$ application is not detrimental to pecan trees, and considering the relatively low cost of $\mathrm{ZnSO}_{4}, 28 \mathrm{~kg} \cdot \mathrm{ha}^{-1}$ is
Marschner, H. 1986. Long-distance transport in the xylem and phloem and its regulation p. 71-102. In: Mineral nutrition in higher plants. Academic Press, New York.

O'Neal, M. E., D.A. Landis, and R. Isaacs. 2002. An inexpensive, accurate method for measuring leaf area and defoliation through digital image analysis. J. Econ. Entomol. 95:1190-1194. 